Erratum

\title{
Erratum: Transferential Memory Spaces in Gisela Heidenreich's Das endlose Jahr. Humanities 2018, 7, 26
}

\author{
Humanities Editorial Office
}

MDPI, St. Alban-Anlage 66, 4052 Basel, Switzerland; humanities@mdpi.com

Received: 11 April 2018; Accepted: 11 April 2018; Published: 19 April 2018

The editorial team would like to make the following changes to the published paper (Becirbegovic 2018):

There is one misspelled word, "Geneaology" in the Heading of Section 1. "The Geneaology of Place: Founding Heimat in the Generationsroman" was corrected to "The Genealogy of Place: Founding Heimat in the Generationsroman".

The word "gedächnis" was revised to Gedächtnis. The first letters of "erfahrung" and "inszenierung" were capitalized in Reference (Assmann 2007):

Assmann, Aleida. 2007. Geschichte im Gedächtnis: Von der individuellen Erfahrung zur öffentlichen Inszenierung. Munich: C. H. Beck.

The first letters of "entdeckung," "biographie" and "lebensbornschicksal" were capitalized in Reference (Heidenreich 2002). Besides, "München" was revised as "Munich":

Heidenreich, Gisela. 2002. Das endlose Jahr: Die langsame Entdeckung der eigenen Biographie—Ein Lebensbornschicksal. Bern: Scherz, Munich: Scherz.

The first letters of "jahre ewigkeit," "liebe," "täter," "diplomat," "dienst" and "endlösung" were capitalized. The first letter of "Deutsche" was changed to lowercase. "München" was corrected to "Munich" in References (Heidenreich 2007) and (Heidenreich 2011):

Heidenreich, Gisela. 2007. Sieben Jahre Ewigkeit: Eine deutsche Liebe. Munich: Droemer.

Heidenreich, Gisela. 2011. Geliebter Täter: Ein Diplomat im Dienst der "Endlösung".

Munich: Droemer.

We apologize for any inconvenience caused to the readers by this change. The changes do not affect the scientific results.

\section{References}

Becirbegovic, Amila. 2018. Transferential Memory Spaces in Gisela Heidenreich's Das endlose Jahr. Humanities 7: 26. [CrossRef]

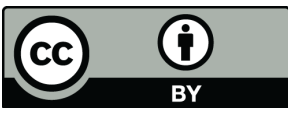

(C) 2018 by the author. Licensee MDPI, Basel, Switzerland. This article is an open access article distributed under the terms and conditions of the Creative Commons Attribution (CC BY) license (http://creativecommons.org/licenses/by/4.0/). 